\title{
Structural Model External and Internal Factors that Influence Students' Mathematical Learning Achievement
}

\author{
Hariani Fitrianti ${ }^{1}$, Andi Saparuddin Nur ${ }^{2}$ \\ Mathematics Education Department \\ Universitas Musamus \\ Merauke, Indonesia \\ ${ }^{1}$ hariani@unmus.ac.id, ${ }^{2}$ andisaparuddin@unmus.ac.id
}

\begin{abstract}
The development of science and technology in various parts of the world is influenced by progress in the field of mathematics. Therefore, the countries that ignore mathematics education as a top priority will be left behind from other countries that provide a place for mathematics as an important subject. But there are many factors that cause students' mathematics learning achievement to be low. The purpose of this study is to model external factors and internal factors that affect the mathematics learning achievement of junior high school students in Merauke. The approach model used in this study is the structural equation model (SEM). The results obtained are (1) the external and internal factors each affect direct mathematics learning achievement, (2) internal factors are not influenced by external factors, and (3) obtained structural models that meet the criteria of fit, absolute comparability, fit and parsimony.
\end{abstract}

Keywords-External Factors; Internal Factors; Mathematics Learning Achievement; Structural Model.

\section{INTRODUCTION}

The development of science and technology in the world is influenced by advances in mathematics. Therefore, the countries that ignore mathematics education as a top priority will miss other countries that make mathematics a priority subject. In addition, mathematics is a source of all disciplines and is also a source of science [1]. Mathematics in Indonesia is given at all levels from elementary school to university. This is because mathematics is a means of thinking logically, systematically, and critically so that it must be mastered by everyone both in terms of their mindset and applied. This proves that mathematics is a very important lesson, but in reality, mathematics is a science that is difficult to understand for most students and learning mathematics requires a high level of ability.

Student learning achievement in Indonesia is still far from expectations compared to other countries. This can be seen from the results of an international survey conducted by Trends in the International Mathematics and Science Study (TIMSS) in 2011 Indonesia ranked 38th out of 42 participating countries and research conducted by The International Association for Evaluation of Educational Achievement (IEA) that mathematics achievement is in the order of 38 of the 39 countries that are the research sample [2][3]. This shows that mathematics achievement in Indonesia is very low. Mathematics achievement decreased in 2012 as evidenced by the results of a survey conducted by PISA (Program of International for Student Assessment) and Organization Economic Cooperation and Development (OECD) where Indonesia ranked 64 out of 65 countries sampled [4][5]. Learning achievement is a reflection of learning outcomes achieved after attending the teaching and learning process. Learning is a process of behavioral change, whether it involves knowledge, skills or attitudes even covering all aspects of the organism or personal thanks to experience and practice [6][7]. This means that success in learning depends on the achievement in the learning process experienced by students, both in the family, school, and residential environment[7].

Merauke is one of the Regencies in Papua Province which is at the eastern end of Indonesia with a population of 209,980 [8]. The majority of the population is of productive age, so it is not surprising that there are many formal and informal educational institutions. For formal education institutions, there are six public junior high schools in Merauke Regency, including SMP Negeri 1, SMP Negeri 2, SMP Negeri 3 dan SMP Negeri 9. Only low levels of basic knowledge of mathematics result in a low level of learning achievement in junior high school students. This has become a complaint about teachers in various junior high schools throughout Merauke Regency. During this time mathematics is seen as a difficult and boring lesson for students. The many formula and pressures to memorize to be one of the causes of mathematics are not lessons that students like. Many students experience stress when they take mathematics lessons.

In general, the factors that influence the learning process are divided into two types, i.e. internal factors and external factors. Both of these factors influence each other so that it determines the quality of learning outcomes. Internal or human factors consist of intelligence, interests, talents, motivation, while external factors or those that come from outside the human include the family environment, school environment and society [6] [9].

In this paper, we used Structural Equation Modeling (SEM) approach for modeling internal factors and external factors that 
affect students' mathematics learning achievement. Structural Equation Modeling (SEM) is a multivariate statistical analysis method that knows the relationship between more complex variables[10]. In addition, the SEM model can solve multilevel models simultaneously which cannot be solved by ordinary multiple linear regression analysis. In addition, the selection of the SEM model is due to being able to analyze the reciprocal relationship model simultaneously, where this model cannot be solved by linear regression analysis simultaneously and able to create construct models as latent variables or variables that are not measured directly, but estimated in the model of measured variables that are assumed to have a relationship with latent variables.

\section{METHOD}

This research was conducted in Merauke with the population observed, i.e. all students of the State Junior High School in Merauke with a total population of 2984 students and the selected sample using a proportionate stratified Random Sampling technique that is 340 students. The variables in this study are external factors $\left(\mathrm{X}_{1}\right)$ consisting of social factors $\left(\mathrm{X}_{11}\right)$, infrastructure facilities $\left(\mathrm{X}_{12}\right)$, curriculum $\left(\mathrm{X}_{13}\right)$, teacher factors $\left(\mathrm{X}_{14}\right)$, internal factors $\left(\mathrm{X}_{2}\right)$ consisting of motivation $\left(\mathrm{X}_{21}\right)$, habits learning $\left(\mathrm{X}_{22}\right)$, learning strategy $\left(\mathrm{X}_{23}\right)$, confidence $\left(\mathrm{X}_{24}\right)$, and mathematics learning achievement $(\mathrm{Y})$ which consists of cognitive achievement $\left(\mathrm{Y}_{1}\right)$, effective achievement $\left(\mathrm{Y}_{2}\right)$, and psychomotor achievement $\left(\mathrm{Y}_{3}\right)$. Data collection techniques used are non-test techniques using instruments in the form of questionnaires to determine internal and external factors that affect student achievement and test techniques using multiple choice test questions to measure student learning achievement. After the data were collected, data analysis was done to model internal and external factors that affect learning achievement using SEM. The SEM modeling steps are (1) assumption test consisting of the number of the samples, normal multivariate data, nonoutliers, and nonmulticollinearity, (2) confirmatory factor analysis was used to analyze the factors of each variable using analysis factors, and (3) structural model analysis using the SEM approach. The analysis used is based on the criteria of goodness of fit [11].

\section{FINDINGS AND DISCUSSION}

The data obtained show the variation of respondents' views on the core of the statement given. Students give an assessment of external and internal factors dominated by individual perceptions related to the school level. The external factors of students from the 4 variables that exist are relatively the same when viewed from the size of data centering and the size of the data distribution. However, when viewed on the size of the data normality in univariate, variables $\mathrm{X}_{12}$ and $\mathrm{X}_{14}$ show chi-square values is 41,7 and 42,09 greater than other external factor variables. Students give a more diverse perception on the X12 and X14 variables because the public junior high schools in Merauke City have not evenly spread infrastructure even for teachers in peripheral schools still relying on temporary teachers who are still in college. Whereas on the other hand there is a State Junior High School that has met the facility standards with professional teachers as teaching staff. All manifest variables (indicators) and latent variables are normally distributed univariately with a p-value $<0.05$.

Meanwhile, the multivariate normality test shows that there are 50 datasets out of sample data. The existence of data outliers that have no known cause requires actions to be taken out of the data set of the sample so that the next analysis stage leaves 290 datasets of samples. The next prerequisite test, which was a multivariate linearity test shows the relationship between variables has a linearity relationship as shown in Fig. 1.

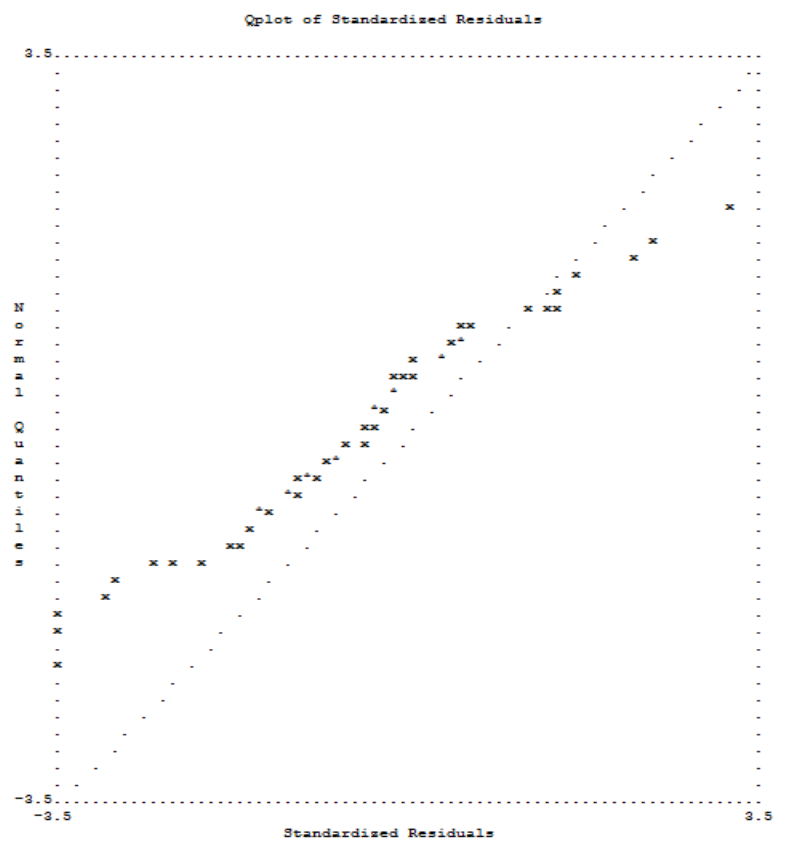

Fig. 1. Variables' linearity relationship

In confirmatory factor analysis, there is a variable Y2 that cannot explain the latent variables so it must be dropped from the model. The results of the analysis after the model is improved show the $\lambda$ factor loading, construct reliability and extracted variance of each variable better than the previous model. The results of the full confirmatory factor analysis can be seen in Fig. 2.

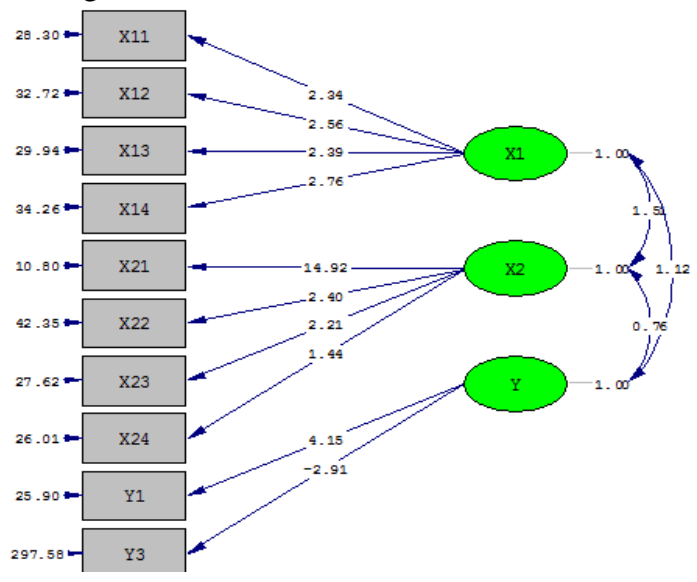

Fig. 2. The result of factor analysis after improvement 
SEM analysis was then carried out to obtain an overview of structural models that affect the mathematics learning achievement of junior high school students in Merauke City. The initial phase structural model is shown in Fig. 3.

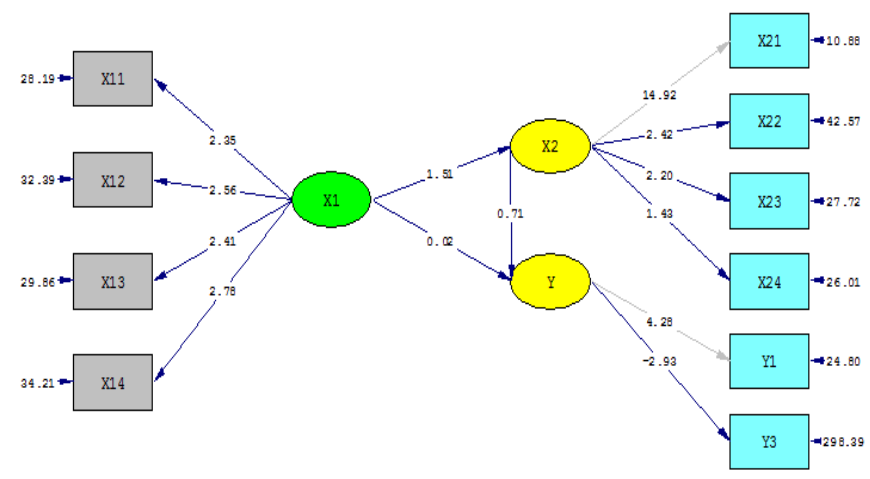

Fig. 3. The result of the initial structural model analysis

The results of the analysis show that $\mathrm{Y}_{3}$ has a negative correlation with $\mathrm{Y}$ of -0.17 which means that $\mathrm{Y}_{3}$ as a $\mathrm{Y}$ indicator is less contributing and even has a negative impact. Therefore, the $\mathrm{Y}_{3}$ variable needs to be dropped from the model so that $Y_{1}$ becomes the only indicator that can explain the $Y$ variables well. Furthermore, variables $X_{1}$ and $X_{2}$ have a correlation of 1.51 which means that error var is negative. A negative error var case can be eliminated by removing the variable correlation that has the case. Therefore, to obtain better modeling, the correlation of $\mathrm{X}_{1}$ and $\mathrm{X}_{2}$ needs to be dropped. The parameter estimation results also show that there is an error var correlation on the variables $X_{12}$ and $X_{14}$. The errorbar correlation between manifest variables indicates the relationship between variables $\mathrm{X}_{12}$ and $\mathrm{X}_{14}$ in constructing variable $X_{1}$. In other words, the measurement models $X_{12}$ and $\mathrm{X}_{14}$ cannot singly explain the $\mathrm{X}_{1}$ variable but there is a relationship between the two. $X_{12}$ and $X_{14}$ are probably a single indicator or composite indicator of $X_{1}$. The results of SEM analysis after model improvement are shown in Fig. 4.

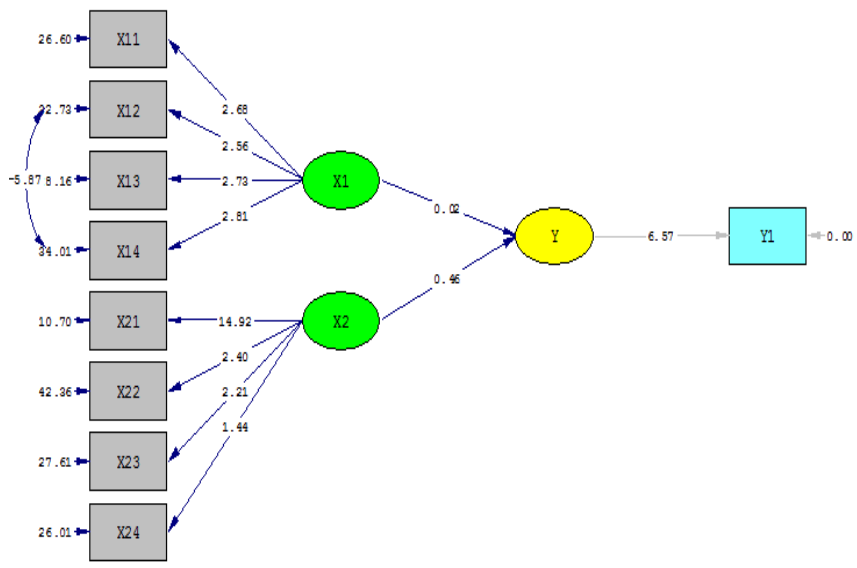

In Fig. 4. it can be seen that the coefficients of each variable greater than 1 with error var are all positive. This indicates that the indicator measurement model of the latent variable is quite good. The coefficient $\gamma$ which connects each latent variable also shows a positive value. This means that the structural equation model can be estimated and used for conclusions. Based on the results of the analysis, the measurement and structural equation models are obtained as in Table 1.

TABLE I. MEASUREMENT AND STRUCTURAL EQUATIONS

\begin{tabular}{|l|l|l|}
\hline Measurement Model & \multicolumn{1}{|c|}{ Equations } & \multicolumn{1}{|c|}{$\boldsymbol{R}^{2}$} \\
\hline$X_{1} \rightarrow X_{11}$ & $\mathrm{X} 11=2.682 \mathrm{X} 1+26.603$ & 0.213 \\
\hline$X_{1} \rightarrow X_{12}$ & $\mathrm{X} 12=2.559 \mathrm{X} 1+32.726$ & 0.167 \\
\hline$X_{1} \rightarrow X_{13}$ & $\mathrm{X} 13=2.735 \mathrm{X} 1+28.164$ & 0.210 \\
\hline$X_{1} \rightarrow X_{14}$ & $\mathrm{X} 14=2.806 \mathrm{X} 1+34.01$ & 0.188 \\
\hline$X_{2} \rightarrow X_{21}$ & $\mathrm{X} 21=14.922 \mathrm{X} 2+10.705$ & 0.954 \\
\hline$X_{2} \rightarrow X_{22}$ & $\mathrm{X} 22=2.4 \mathrm{X} 2+42.36$ & 0.12 \\
\hline$X_{2} \rightarrow X_{23}$ & $\mathrm{X} 23=2.207 \mathrm{X} 2+27.61$ & 0.15 \\
\hline$X_{2} \rightarrow X_{24}$ & $\mathrm{X} 24=1.44 \mathrm{X} 2+26.01$ & 0.074 \\
\hline$Y \rightarrow Y_{1}$ & $\mathrm{Y} 1=6.569 \mathrm{Y}$ & 1 \\
\hline Structural Model & Equations & $\mathrm{R} 2$ \\
\hline$X_{1,2} \rightarrow Y$ & $\mathrm{Y}=0.0152 \mathrm{X} 1+0.459 \mathrm{X} 2+0.77$ & 0.23 \\
\hline
\end{tabular}

In table 4.3. It is seen that $\mathrm{X}_{21}$ is the most dominant indicator of $\mathrm{X}_{2}$ formation among other variables. The $\mathrm{R}^{2} \mathrm{X}_{21}$ coefficient is very high compared to other $X_{2}$ indicators and even $\mathrm{X}_{24}$ does not reach $10 \%$. Meanwhile, variable $\mathrm{X}_{1}$ is formed by indicators with $\mathrm{R}^{2}$ coefficients between $16 \%$ and $22 \%$. This indicates that each construct indicator of $X_{1}$ is not too dominant and tends to contribute not large. The existence of a composite $\mathrm{X}_{1}$ construct that is $\mathrm{X}_{12}$ and $\mathrm{X}_{14}$ contributes to the low R2 coefficient. Nevertheless, all constructs $X_{1}$ contribute significantly to the latent variables. Furthermore, as a result of the path model $X_{1}$ to $X_{2}$ being eliminated, the structural equation model becomes single. $\mathrm{Y}$ can only be explained directly by $\mathrm{X}_{1}$ and $\mathrm{X}_{2}$ without going through a moderator variable. The $\mathrm{R} 2$ coefficient of structural equation $\mathrm{Y}$ is $23 \%$ more dominated by the contribution of $\mathrm{X}_{2}$ which can be observed from the magnitude of the coefficient on the model. This indicates that $\mathrm{X}_{2}$ is a more dominant factor influencing the mathematics learning achievement of State Junior High School students in Merauke City compared to $\mathrm{X}_{1}$.

The path diagram model in Fig. 4. analyzed the degree of suitability of the mode for generalization using Goodness of Fit Indicator (GFI). Based on the results of the GFI SEM model obtained the description as shown in table 2 .

Fig. 4. Structural model after improvement 
TABLE II. GFI Analysis of the Final Stage Model

\begin{tabular}{|l|l|l|}
\hline \multicolumn{1}{|c|}{ Goodness of fit indicates } & \multicolumn{1}{|c|}{ Criteria } & \multicolumn{1}{c|}{$\begin{array}{c}\text { GFI } \\
\text { results }\end{array}$} \\
\hline chi-square statistic $\left(\chi^{2}\right)$ & $\chi^{2}>0,5$ & 41.14 \\
\hline P-Value & $p>0,05$ & 0.087 \\
\hline RMSEA & $R M S E A<0,08$ & 0.03 \\
\hline GFI & $G F I>0,9$ & 0.901 \\
\hline AGFI & $A G F I \geq 0,9$ & 0.913 \\
\hline CMIN/DF & $C M I N / D F \leq 2,00$ & 1.708 \\
\hline TLI & $T L I \geq 0,95$ & 0.955 \\
\hline CFI & $C F I \geq 0,95$ & 0.961 \\
\hline
\end{tabular}

The results of the GFI analysis of the final stage model compared to the GFI criteria show that the model is fit and suitable for generalization. GFI has several size descriptions, such as the measure of absolute suitability, comparative suitability measures, and the size of the parsimony suitability. The description of each size is described as follows:

1. Size of absolute suitability shows a value of $\chi^{2}$ of 41.14 , pvalue $=0.087$, and $\mathrm{RMSEA}=0.03$. The value of $\chi 2$ tends to be largely due to the sample size so that the $p$-value is relatively small. However, relatively small RMSEA values indicate that the sample covariance matrix tends to be no different from the population covariance matrix. Meanwhile, the GFI value of 0.901 means that the model has conformity with the data of $90.1 \%$ or the model is able to estimate the population covariance matrix which is not different from the sample covariance matrix of $90.1 \%$.

2. The comparative suitability measure shows AGFI $=0.913$, $\mathrm{TLI}=0.955$, and CFI $=0.961$. A comparative suitability measure shows the ability of the proposed model when compared with the baseline model [12]. AGFI size of 0.913 means that the model can estimate the sample covariance matrix of $91.3 \%$ after adjusting for the model's freedom degree, i.e. $\mathrm{df}=24$. The CFI value of 0.961 means that the model size is $96.1 \%$ better than the baseline model.

3. The size of the parsimony suitability is related to the simplicity of the proposed model with fewer and more effective path diagrams than alternative models. The measure of conformity of parsimony can be seen from the CMIN / DF value which is less than 2. The CMIN / DF value of 1.708 is obtained from the comparison of the value of $\mathrm{f} 2$ with the $\mathrm{df}$ value indicating the model is parsimony compared to the alternative model.

Mathematics learning achievement cannot be separated from three domains, i.e. cognitive, effective, and psychomotor achievement. However, it cannot be denied that mathematics learning achievement is more dominated by students' cognitive achievement [13]. The results of data analysis obtained by school facilities and infrastructure have a relationship with teacher factors as a construct indicator of external factors. School facilities and infrastructure may be affiliated with students' perceptions of teaching mathematics teachers. Teachers with good qualifications will think about the availability of adequate learning facilities such as learning media or conducive classroom atmosphere [14]. In addition, inadequate classroom conditions accompanied by a lack of learning media cause students to be apathetic about mathematics. Students need a conducive classroom and learning atmosphere that enables classroom interactions [15].

Interaction in the classroom is a necessity to create effective and enjoyable learning. Social factors are important variables that students need to learn. Through socialization, teachers will be able to recognize the potential and needs of students in learning. Students with good learning achievement in mathematics are generally less able to socialize and tend to be closed [16]. In line with the results of this study, social factors only contribute under $25 \%$ to the external factors of students in achieving mathematics learning achievement. The social factors that students receive are more dominant than those of parents and neighborhoods. Parenting patterns have an influence on students' mathematics learning achievement, but the contribution given is not too large [17].

The results of the study also revealed that the application of the curriculum had not contributed greatly to students' mathematics learning achievement. The curriculum is perceived by students in general so that the learning process used by the teacher is assumed to be still the same as the previous curriculum. The curriculum is an instrument that is raw material. The success of the application of the curriculum is the result of the feeling and intention of the teacher so that the achievement of learning mathematics can be achieved if the teacher is able to apply the curriculum well [18]. The results of the analysis show that there are still many factors outside the variables studied that affect mathematics learning achievement. These indications can be observed in the presence of economic, health, and cultural perceptions of students that have not been studied in the model [19].

Furthermore, internal factors are the driving force that arises from a person to achieve. In internal factors, motivation is the most dominant construct indicator. Motivation affects the achievement of learning mathematics directly [17] [20]. The contribution of motivation as an indicator of constructs of external factors is greater than $90 \%$ which indicates that most of the students' internal mathematics learning achievement is generated from motivation. This is inversely proportional to indicators of study habits which only contribute $7 \%$ as an indicator of internal factor constructs. Understanding mathematical concepts in a structured manner are better than learning because of memorization or study habits that are less optimizing reasoning abilities[13]. Confidence and learning strategies each contribute $12 \%$ and $15 \%$ in shaping the construct of internal factors. Confidence is a good capital owned by students, but most students who lack confidence show better mathematical abilities [21]. Learning strategies used by students are not necessarily effective and provide optimal results for learning achievement. This can be caused by the material being studied only in the context of the content not in the context of meaning. Students tend to use learning strategies only at the time of the exam, but do not pay attention to the substance of the material during face-to-face meetings [22]. 
Based on the structural model, internal factors contribute more to the learning achievement of mathematics. This is in line with the results of the study [17][20] which revealed that internal factors predominantly influence learning achievement. The results of this study also show that external factors do not significantly influence internal factors of students. External factors directly affect mathematics learning achievement so that external factors and internal factors become independent exogenous variables in this study. The results of this study are not in line with the opinion of DEF who found a relationship between external and internal factors in influencing mathematics learning achievement. However, according to [20] external factors do not always determine a person's internal factors, especially if there are other variables that are not measured in the research model, it turns out to have a major contribution in determining mathematics learning achievement. In the context of state junior high school students in Merauke City, the results of the study [17] show that external factors such as parenting parents do not always determine their internal factors. Sometimes students with good external factors actually make their internal factors unfavorable so that they do not affect their mathematics learning achievement.

\section{CONCLUSION}

Based on the research findings and discussion, the conclusion of the study that answers the problem formulation is as in the following:

1. External factors and internal factors affect the achievement of mathematics directly. Construction of external and internal factors can be explained well by the indicators, but indicators of facilities and infrastructure with teacher factors produce a composite construct in explaining external factors, while constructs of learning achievement in mathematics can only be explained well by cognitive achievement.

2. Internal factors are not significantly influenced by external factors so that external factors and internal factors become independent exogenous variables without moderator variables.

3. A structural model is obtained that meets the criteria of the fit model, the size of the suitability is absolute, comparative, and parsimony. The resulting structural model is able to estimate the sample covariance matrix, not unlike the population covariance matrix.

\section{ACKNOWLEDGMENTS}

Acknowledgments were conveyed to the DRPM Dikti who has funded this program through beginner lecturer research scheme with a contract number 042.10/UN52.8/LT/2018.

\section{REFERENCES}

[1] Dimayati and Mudjiono, Belajar dan Pembelajaran. Jakarta: Rineka Cipta, 2013.

[2] Yuzarion, "Faktor yang mempengaruhi prestasi belajar peserta didik," Ilmu Pendidik., no. 1996, 2012.
[3] D. Qondias, E. Firdaus, and I.W. Juliawan, "Analisis Structural Equation Modelling (SEM) Dalam Mengidentifikasi Pengaruh Intensitas Social Network Sebagai Sarana Belajar Dan Motivasi Belajar Terhadap Prestasi Belajar di STKIP Citra Bakti,” J. Ilm. Pendidik. Citra Bakti, vol. 3, pp. 11-22, 2016.

[4] O.H. Sholikhah, Budiyono, and D.R.S. Saputro, "Eksperimentasi Model Pembelajaran Kooperatif Tipe Group Investigation ( GI ) Dan Numbered Heads Together ( NHT ) Pada Materi Garis Singgung Lingkaran Ditinjau Dari Kecerdasan Majemuk Siswa Kelas VIII SMP Negeri SeKota Madiun Tahun,” J. Elektron. Pembelajar. Mat., vol. 2, pp. 727 739, 2014.

[5] W.I. Disai, A. Dariyo, and D. Basaria, "Hubungan Antara Kecemasan Matematika dan Self-Efficacy Dengan Hasil Belajar Matematika Siswa SMA X Kota Palangka Raya,” J. Muara Ilmu Sos. Hum. Seni, vol. 1, pp. $556-568,2018$.

[6] S. Djamarah and A. Zain, Strategi Belajar Mengajar. Jakarta: Rineka Cipta, 2013.

[7] M. Syah, Psikologi Belajar Mengajar. Jakarta, 2009.

[8] BPS Kabupaten Merauke, Kabupaten Merauke dalam Angka Tahun 2014. Merauke: BPS Merauke, 2014.

[9] Slameto, Belajar dan Faktor- Faktor yang Mempengaruhi. Jakarta: Rineka Cipta, 2013.

[10] D.W.I. Rachmayani, “ISSN 2338-2996," vol. 2, pp. 13-23, 2014.

[11] S. Faizal and I. Sudarjo, "Pendekatan Metode Struktural Equation Modelling (SEM) untuk Analisa Persepsi Pegawai Terhadap Gaya Kepemimpinan di Industri Manufaktur (Studi Kasus PT. Ferro Sidoarjo).," [in Sem. Nas. Manaj. Teknol. XVIII, 2013, p. A-11-1-A-118].

[12] Kusnendi, Model-Model Persamaan Struktural Satu dan Multigroup Sampel dengan Lisrel. Bandung: Alfabeta, 2008.

[13] A.N. Hayati, "Pengaruh Kebiasaan Belajar Dan Perhatian Orang Tua Terhadap Hasil Belajar Kognitif Matematika," J. Pendidik. Guru Sekol. Dasar, vol. 13, pp. 224-232, 2016.

[14] M. Fitrah, "Mengidentifikasi Faktor Penghambat Guru Matematika Mengidentifikasi Faktor Penghambat Guru Matematika Kecamatan Dompu NTB Terhadap Proses Pembelajaran pada Sekolah Menengah Atas," J. Hasil Penelit. Kaji. Kepust. Bid. Pendidik. Pengajaran Pembelajar., vol. 15, 2016.

[15] A.D. Saraswati and A. S. Purnami, "Matematika Siswa Kelas VIII SMP Negeri Se-Kecamatan Pleret Bantul," pp. 154-161, 2017.

[16] Nurhaja and Suhar, "Pengaruh Disposisi Matematik dan Dukungan Sosial Terhadap Prestasi Belajar Matematika Siswa SMA Negeri 7 dan SMA Negeri 9 Kendari,” J. Penelit. Pendidik. Mat., vol. 3, pp. 107-120, 2015.

[17] A.S. Nur and B. Massang, "Pengaruh Pola Asuh Orang Tua, Konsep Diri , dan Motivasi Berprestasi terhadap Prestasi Belajar Matematika Siswa Kelas IX SMP Negeri di kota Merauke," Suska J. Math. Educ., vol. 2, pp. 89-96, 2016.

[18] D. Kusnadi, S. Tahmir, and I. Minggi, "Implementasi kurikulum 2013 dalam pembelajaran matematika di sma negeri 1 makassar," J. Mat. dan Pembelajaran, vol. 2, pp. 123-135, 2014.

[19] S.H. Mustamin and S. Sulasteri, "Faktor-faktor yang mempengaruhi prestasi belajar mahasiswa jurusan pendidikan matematika fakultas tarbiyah dan keguruan uin alauddin makassar," J. Mat. dan Pembelajar., vol. 1, pp. 151-177, 2013.

[20] A. Syukriani, "Model Struktural dalam Menilai Antar-Hubungan antara Faktor Internal dan Faktor Eksternal terhadap Prestasi Belajar Matematika Siswa Kelas X SMA Negeri di Kota," J. Sainsmat., vol. II, 2013.

[21] Sardin and W.O. Nurmita, "Pengaruh Kepercayaan Diri Terhadap Prestasi Belajar Matematika Siswa di SMP Negeri 1 Batauga," Eduk.: J. Penelit. Artikel Pendidik., vol. 9, pp. 43-54, 2017.

[22] H. Nasutio and H. Sitompul, "Pengaruh Strategi Pembelajaran dan Kreativitas Terhadap Hasil Belajar Matematika," J. Tabularasa PPS UNIMED, vol. 12, pp. 268-284, 2015. 